\title{
Cultural Diversity, Ecodiversity, and Music Education
}

\author{
Vincent C. Bates, Daniel J. Shevock, and Anita Prest
}

\begin{abstract}
Diversity discourses in music education tend toward anthropocentrism, focusing on human cultures, identities, and institutions. In this chapter, we broaden conceptualizations of diversity in music education to include relationships between music, education, and ecology: understood as interactions among organisms and the physical environment. Diversity in music education can be realized by attending to the ongoing interrelationships of local geography, ecology, and culture, all of which contribute dynamically to local music practices. We situate our analysis within specific Indigenous North American cultures (e.g., Western Apache, Nuu-chahnulth, Stó:lō, and Syilx) and associated perspectives and philosophies to shed light on the multiple forms of reciprocity that undergird diversity. Indigenous knowledge, in combination with new materialism and political ecology discourses, can help us come back down to earth in ways of being and becoming that are ecologically sustainable, preserving the ecodiversity that exists and grows in place, forging egalitarian relationships and a sense of communal responsibility, fostering reverence for ancestors along with nonhuman lives and topographies, and cultivating musical practices that are one with our respective ecosystems.
\end{abstract}

Keywords Ecodiversity · Music education - Indigenous - Cultural diversity · Place · Local

\footnotetext{
V. C. Bates $(\bowtie)$

Department of Teacher Education, Weber State University, Ogden, UT, USA

e-mail: vincentbates@weber.edu

D. J. Shevock

Misciagna Family Center for Performing Arts, Pennsylvania State University Altoona, Altoona, PA, USA

e-mail: djs541@psu.edu
}
A. Prest
Department of Curriculum and Instruction, University of Victoria, Victoria, Canada
e-mail: aprest@uvic.ca 


\section{Introduction}

When people discuss diversity in music education, they are usually referring to differences among social groups and institutions, often with political aims of promoting equity and culturally sensitive teaching relative to race, gender, and sexuality. Sometimes other considerations such as dis/ability, class, and religion come into play, but even the most inclusive and intersectional analyses tend to be anthropocentric - centered on human experiences, needs, and desires, regardless of impacts on nonhuman beings and places. In this chapter we embrace a holistic view of music and education, situating human diversity within ecodiversity (plant and animal life, water, minerals, landforms, weather, and so forth), thereby extending the scope of diversity and justice to include political concerns about climate change, ecosystem destruction, and extinction, while also deepening understandings essential to overcoming human oppression, domination, and exploitation. In other words, we believe that a more complete vision of justice, encompassing all environmental considerations, can serve to level both human and human/nonhuman hierarchies. To these ends, we first review relationships between cultural diversity and ecodiversity, outlining an ecocentric vision that blurs distinctions between culture and nature and places music as an element of diversity within ecosystems. Next, we consider biocultural perspectives of some Indigenous North American musical cultures in which sound, song, stories, spirituality, and sentient beings are bound up and intertwined with conceptions of place (understood in this chapter as physical geography). Finally, we recommend efforts in fostering ecodiversity in and through music education as means to environmental sustainability.

\section{Ecodiversity}

How we perceive diversity in this chapter reflects the confluence of multiple scholarly streams. Within the field of sociology, new materialism recognizes that humans are just "one materiality among many"-a perspective that "has the consequence of cutting across animate/inanimate and human/animal dualisms that underpin the natural and social science conceptions and systems of privilege" (Fox and Alldred 2017, p. 25). In addition, political ecology maintains a "theoretical commitment to critical social theory and a post-positivist understanding of nature and the production of knowledge about it, which views these as inseparable from social relations of power" (Bridge et al. 2015, p. 7). Finally, new materialism and political ecology correspond with myriad Indigenous perspectives (MacLure 2016). For instance, in the Diné (Navajo) philosophical ideal of hózhó, four facets of "holistic living and learning"-cognitive, physiological, psychological, and intuitive-are "embedded in and reflective of the natural processes of nature and cosmos" (Werito 2014 , p. 27). This reflects a general tendency among human cultures living in close proximity to nonhuman environments, Indigenous groups in particular, to adopt 
more inclusive and less anthropocentric perspectives (Esteva and Prakash 2014). Our own concerns about ecological sustainability seem to have grown from our respective origins, experiences, and work in rural music education (e.g., Bates 2013; Prest 2013; Shevock 2017). We tend to see anthropocentrism at work in environmentally destructive forces (e.g., industrialization, urbanization, militarism, and consumerism), which are present in educational institutions through teachers' pedagogical practices and in stated and hidden forms of curriculum. Holistic, Indigenous, rural, and new materialist perspectives offer environmentally sensitive alternatives to these forces.

An ecological perspective-where ecology is understood in its fullness and musical practices are situated as material realities within and among all other elements of nature (see Allen and Dawe 2016) — can expand the ways in which we think about music and music education. This ecological grounding is evident in Shevock's (2017) broad definition of music as "the intentional experiencing of sound" (p. 41), without centering humans as the ones intending and/or experiencing. Teacher, learner, and musicker (e.g., one who makes music) roles can be filled by a variety of entities, from people and birds to rivers and trees. A political ecology of music education can thereby help flatten current hierarchies, human or otherwise, and extend justice beyond the anthropocentric. Because this leveling envelops human hierarchies (Fox and Alldred 2017), it can also help music educators recognize "intersections between ... ecological crises, racial injustice, patriarchy, and economic stratification" (Shevock 2017, p. 110). This shift in thinking, difficult as it might seem for those of us socialized within anthropocentric Western paradigms, has important implications for how we perceive and the values we place upon cultural and natural diversity and, hence, music education. We will discuss four of these implications.

First, musical practices are integral elements in ecodiversity (Allen and Dawe 2016; Shevock 2017). They emerge in diverse landscapes alive with acoustic properties within which people and other organisms act and interact (Elsey 2013; Sercombe 2009). Within an ecological framing, people, along with other entities, affect rather than make music. In other words, musicking is a rich acoustic interaction or collaboration among living organisms and their environments. This necessarily situates human actions, including musical and educational actions, within geographical places-shared ecosystems abundant with plant and animal life, weather patterns, water cycles, and landforms (Titon 2016).

Second, ecodiversity develops within distinct geographical places and ecosystems. 250 million years ago, all land on earth existed in a single mass: Pangea. The separation of Pangea into continents led to increased species diversity (Jordan et al. 2016), the proliferation of which continued as organisms evolved to fit well within particular places (Ehrlich and Wilson 1991). This growing and evolving diversity eventually included humans and our cultural practices. Diverse musics evolved to reflect the ecosystems to which they were inextricably bound. Such rootedness is noted by Helena Simonett (2016) in her description of Indigenous Yoreme music making in Northwestern Mexico. In the fiesta, the performers merge with the world around them: musicking, singing, and dancing obscure the boundaries between 
humans, nonhumans, and environment. Musicians and dancers transform into the animals with whom they co-inhabit juiya annia, the "enchanted world" (p. 106).

Third, ecodiversity has both inherent and instrumental value. A core tenet of ecomusicology (see Allen and Dawe 2016) is that musical practices, as with all other ecological elements, have value within the ecosystems in which they are situated, growing as they do from various acoustic affordances. Furthermore, diversity is integral to overall well-being within ecosystems. Titon (2016) puts this in musical terms: "The healthier the habitat, the more 'musical' the polyphony of the creatures that occupy it" (p. 78). Due to this dynamic interconnectedness, to harm any aspect within an ecosystem, musical or otherwise, inflicts harm on diverse others.

Fourth, globalization can diminish ecodiversity, including cultural diversity. Globalization has been referred to as a New Pangea, recombining the continents through international travel and trade and thereby threatening ecological diversity (Lewis and Maslin 2018). This diminishment includes the loss of cultural diversity, as values, languages, and musics of a global culture replace the values, languages, and musics of diverse local cultures (see Snyder et al. 2003). The extractive forces of global multiculturalism can be especially harmful; when diverse species are separated from an already diverse ecosystem-a "web of interwoven lives" (Carson 2002, p. 56; Shevock 2017) — and are put in artificial isolation, they are apt to wither and die. Schippers (2016) raises this concern about the work of making audio recordings and otherwise attempting to preserve, through extraction, diverse musical practices: "these efforts do not always provide sufficient basis for the actual survival of music practices as part of an unbroken, living tradition, which many will argue is a key condition for maintaining the essence (explicit and tacit, tangible and intangible) of specific styles and genres" (p. 3).

An ecocentric outlook recognizes ample diversity within ecosystems and situates music first and foremost within that diversity. Complex musical practices emanating from a vast array of geological/biological forces have just as many or more points of diversity when compared with human cultural diversity. We agree with those who argue that diversity can be integral to developing empathy (e.g., Clarke et al. 2015) and suggest that diversity within an ecosystem serves that purpose at least as well as diversity across cultures. Kymlicka and Walker (2012) go so far as to suggest: "People must first be successfully socialized into the habits of moral particularism before they are epistemologically or psychologically capable of morally engaging with the claims of distant others" (p. 4). We argue that respect for diversity relies on respect for localism on its own terms, or in other words, a grassroots "pluriverse" (Esteva and Prakash 2014). Diversity, put simply, is enhanced when local communities nurture distinct, dynamic, evolving practices.

\section{Indigenous North American Philosophies}

Indigenous cultural practices on Turtle Island (an original name for North America used by multiple Indigenous groups) reflect the situatedness of culture within ecological diversity and illustrate nonhierarchical forms of expression in which 
sound, song, stories, spirituality, and sentient beings are bound up and intertwined with conceptions of place. The examples we offer below reflect conceptions of music that highlight the importance of relationships among all beings, past and present, who exist in a place. Although the Indigenous and non-Indigenous scholars we cite here have focused on the cultural practices that they have experienced, each reflecting unique worldviews, we emphasize that the living cultural practices they describe are not static, do not exist in isolation, and change over time. Among Indigenous groups on Turtle Island, cultural diversity is the rule-there are approximately 70 Indigenous languages spoken in Canada, 150 in the USA, and 89 in Mexico. We also wish to acknowledge our positions as non-Indigenous music education scholars who are engaged in learning Indigenous ways of knowing and their relation to cultural practices and the possibilities they afford to think about diversity and sustainability in music education.

The Dane-Zaa are a northern Athapaskan hunting people in northeastern British Columbia who "are profoundly egalitarian ... [and] deeply committed to communal responsibility, extending beyond relations between humans to include relations with the non-human persons who make up the natural environment" (Ridington and Ridington 2006, p. 217). For the Dane-Zaa, nonhuman persons include animals and ancestors. Dane-Zaa songs (naachene-yina), stories, and dances manifest this worldview, as they "honor the ancestors and spiritual places of the Dane-Zaa land" (Ridington and Ridington 2006, p. 27). Songs are conceived as hunting trails; their melodic lines represent the twists and turns, ups and downs of an animal's trail that hunters follow, and the drumbeat accompanying the songs evokes hunters' footsteps. Dances are physical manifestations of the trails and relationships between humans, their ancestors, and the animals they hunt. Dreamers-people in the community whose job is to communicate with ancestors through out-of-body experiencesbring these songs back to the community. The mental trails that people create as they sing and dance to naachene-yina are pathways back to their ancestors, facilitating ongoing relationships with them. Likewise, the metaphor of a trail also evokes the reciprocal relationship between people and animals, as the Dane-Zaa traditionally relied on animals for sustenance and consciously acted in ways that showed respect for the life-forms that shared their environment.

Further south, in the central interior of British Columbia and along the Fraser River, Stó:lō and Secwépemc peoples also note the ways in which people, other organisms, and land interact, giving rise to poetic expressions (Elsey 2013; Ignace and Ignace 2018). It is through these expressions that "the land gets encoded into a territorial system of meaning, on an epic or folkloric scale, and is a primary aspect of collective selfhood and identity of the people" (Elsey 2013, p. 50). Elsey suggests that, for the Stó:lō (and others), songs - in addition to their role in expressing identity to a specific territory-convey the meaning of the land and the possibilities it affords. Community members' relationships to the land are embodied through stories, artwork, songs, and dances, representations of their individual and collective experiences over time. For the Secwépemc, "toponyms [or place names derived from topographical features] imply an entire system of references and relationships in the landscape" (Ignace and Ignace 2018, p. 234), invoking information on the "kind of animals, plants, sources of water, and shelter can be found at or near a place that is 
mentioned" (p. 235). Such place-names are oral "deeds to the land" (p. 254) because they articulate reciprocal relationships among people, ecological knowledge, and ancestral experiences on that territory. The following Welcome Song attests to the importance of relationships in Secwépemc tradition:

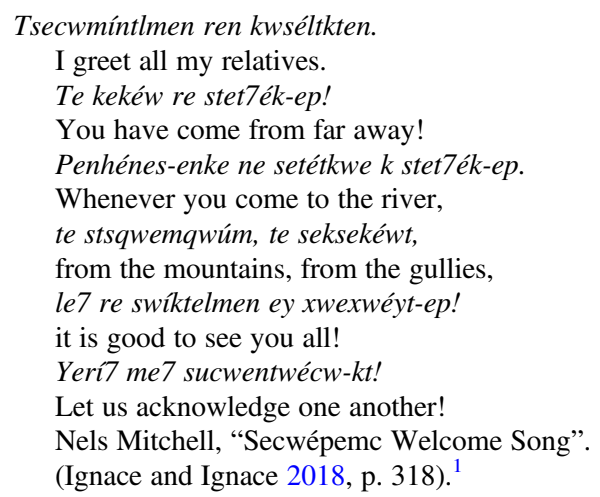

Yet further south in the place currently known as Arizona, Basso (1996) shines a light on "the significance of place in Apache thought and practice" (p. xv). His longterm study on behalf of the White Mountain Western Apache consisted of mapping approximately 300 places they identified as important to them, the names and stories associated with those places, and the ways in which place-names and respective teachings are bound up in everyday conversations. Similar to the Secwépemc and other Indigenous peoples, the Western Apache have developed relationships to specific and visually unique places through the historical events that they or others have experienced in those places. The evocative names given to these places constantly stimulate consideration of those historical events, the lessons learned from them, and the relationships that they bring to mind, also reaching "deeply into other cultural spheres, including conceptions of wisdom, notions of morality, politeness and tact in forms of spoken discourse, and certain conventional ways of imagining and interpreting the Apache tribal past" (Basso 1996, p. xv). Western Apache "relationships to places ... find expression through the agencies of myth, prayer, music, dance, art, architecture, and ... forms of religious and political ritual" (Basso 1996, p. 109); thus, music and other cultural practices are expressions and repositories of Western Apache collective wisdom (igoyá 'i) required for survival. Self-reflexive individuals who journey on the trail of wisdom cultivate mental smoothness, resilience, and steadiness (p. 133) by developing "keen and unhurried reasoning, resistance to fear and anxiety, and suppression of emotion born of hostility and pride ... through extended reflection on symbolic dimensions of the physical environment" (p. 146). Place, musical expression, wisdom, and the capacity to survive are inextricably bound together.

\footnotetext{
${ }^{1}$ This song, like all other Secwepemc cultural property, represents the Indigenous intellectual property of the Secwepemc people, as stated in Ignace and Ignace 2017, p. xi.
} 
The Nuu-chah-nulth people, who live on Vancouver Island, also view ecosystems, musical expression, personal and communal integrity, and survival as interconnected. Songs link the physical realm to the spiritual realm and all sentient beings within physical existence to each other (Atleo/Umeek 2004). Songs are expressions of the Nuu-chah-nulth constitutional principles of recognition, consent, continuity, and respect. For example, the Nuu-chah-nulth enact the principle of recognition at feasts where those who have been invited receive gifts (including songs), which "promote balance and harmony between beings" (p. 80). The principle of recognition extends "to include both people and the living environment" (p. 84). Likewise, the notion of consent, "a kind of consensus that reality is characterized by purposeful diversity" (p. 93), acknowledges both the importance of individual self-expression and the need for "balance and harmony within the diversity of community" (p. 95). In this view, community is understood broadly to include the entire ecosystem and the beings that inhabit it; therefore, individual selfexpression enhances both individual and ecological well-being. Consent leads to the continuity of and respect for all living things because "all life forms have value and all are to be allowed to continue to live sustainably because of this value" (Atleo/ Umeek 2011, p. 117).

Crucially, Atleo/Umeek (2011) states that these principles provide humans with a means to solve our global problems, a framework for "working to transform the inherent contradictions of reality into a sustainable balance and harmony so that all life forms can continue to live" (p. 58). Atleo/Umeek (2011) uses the metaphor of music to illustrate diversity:

\footnotetext{
A piece of music can have many variations and interpretations. Yet, in spite of variations in the way specific notes are played, the musical theme remains the same ... in spite of the multiple interpretations of each piece of music or dance, the original musical score or dance routine can be identified. (Atleo/Umeek 2011, p. 121)
}

He uses this metaphor to suggest one way to arrive at consensus when attempting to resolve our global crises; he encourages us to focus on those musical themes or shared attributes that we hold in common despite our different interpretations so that we might arrive at consensus regarding those we all hold most dear. In learning to "co-manage our common reality," we, as multiple species, survive. For Atleo/ Umeek (2011), "survival... is, metaphorically speaking, like harmonious music" (p. 122). Thus, across North America, for Indigenous peoples, diversity in musical expression is representative of and dependent on rich and diverse ecologies, geographies, and histories, which have cultivated unique insights that might offer humanity pathways to ecological sustainability.

\section{Music Education for Ecological Sustainability}

In October 2018 the Intergovernmental Panel on Climate Change (IPCC 2018) released a report giving a dire warning about "the impacts of global warming of $1.5^{\circ} \mathrm{C}$ above pre-industrial levels" and calling for an urgent "global response to the 
threat of climate change, sustainable development, and efforts to eradicate poverty." We believe that music educators can and should play a role-through their professional responsibilities as music educators - in addressing ecological crises and their impacts. Many schools have environmental education programs aimed at connecting students with and increasing their understandings of nature. However, as Fletcher (2017) postulates, these programs can end up reifying perceived divisions between culture and nature: "The idea that one could be disconnected from 'nature' ... is fundamentally grounded in a culturally specific nature-culture dichotomy, for without this sense of strict separation between the human and nonhuman realms this particular perception of alienation would not be possible" (pp. 228-229). When people recognize that they are part of rather than separate from or above the "morethan-human world" (p. 232), on the other hand, they may be more likely to recognize and care about the readily apparent environmental destruction around them.

Ecologically diverse approaches to music and musicking, such as the Indigenous perspectives outlined in this chapter, can engage students in experiences that embrace the inseparability of planetary diversity and see themselves as part of the whole. We do recognize the dynamic and evolving nature of Indigenous cultural practices and caution against romanticizing or essentializing cultural ecologies. In this light, Yeh and Bryan (2015) propose a political ecology that understands "Indigenous peoples as living [within] modern forms of economy and power-states and capital -in ways that [recognize] their embeddedness within colonialism, slavery, war, and capitalist exploitation" (p. 533). Nonetheless, we believe that music educators can draw insight from Indigenous and other ecocentric perspectives on music, teaching, and learning to shape curriculum and instruction in ways that further the goals of education for environmental sustainability.

The International Convention on Biodiversity, in 1992, "acknowledged the role of traditional lifestyles of Indigenous people related to the conservation of biodiversity, and recognized their property rights to biodiversity and associated knowledge" (Blanc and Soini 2015, p. 77). Music educators in Indigenous communities or in schools with any percentage of Indigenous students have a responsibility to help maintain these traditions as dynamic adaptive processes based in holistic conceptualizations of ecodiversity. Music educators in both rural and metropolitan settings can also introduce Indigenous cultural traditions appropriately to non-Indigenous music students; these traditions can potentially teach all students something about their own places in the world and responsibilities to care for the natural environment. Indigenous philosophies, as outlined in this chapter, provide an alternative to the Western anthropocentrism that has precipitated current climate crises. Henderson and Zarger (2017) write: "Acknowledging the profound inseparability among humans, non-human species, and the environment is paramount to understanding links between education and behavior, or learning and doing, and how these relationships are produced in pedagogical spaces" (Henderson and Zarger 2017, p. 286). Thus, rather than breadth, pedagogical approaches involving Indigenous music should emphasize enough depth to get at ecological understandings integral to Indigenous practices.

Ecodiversity can be fostered as each local community works, through schooling as well as through other means, to preserve its distinct practices and ways of living 
well in place. Too often, particularly for White and majority students, multicultural music education (in which Indigenous musics traditionally play a part) is focused on "exposing" students to a diversity of distant cultures, drawing minds and hearts away from local places. We believe that students have a right to initially experience musical heritages in school that reflect the places where they live. Too often, educational discourses elide local ecosystems, even to the extent of promising "social mobility" intended to "liberate" children from local places, culturally and physically; in the words of Prakash and Esteva (2008), "children learn to leave home, not to stay home" (p. 3). On the other hand, conceptions that enculturate students to honor geographical, ecological places can serve to perpetuate diverse local cultures and preserve natural environments. Redirecting the scholarly gaze beyond the anthropocentric, in this way, is a necessary antecedent in forging sustainable alternatives to currently destructive trajectories.

Music educators can be influential in foregrounding local musical traditions and emphasizing musicking within local contexts of community and family, especially with the guidance of local human and nonhuman musickers. Where possible, music educators can have students of all backgrounds research their own placed histories and try to uncover musics and stories connected to the ways their ancestors related to the natural world. Thus, children may begin to find alternative ways to live regeneratively in place. This rerooting praxis (Shevock 2017) is in line with Weil's (2002/1949) "need for roots," which stands at odds with uprooted global, technological ways that can make flourishing difficult, to say the least, considering the previously mentioned threats human "progress" poses to Earth's ecosystems. For Weil, rooted collectivities preserve the past as "the sole agency for preserving the spiritual treasures accumulated by the dead, the sole transmitting agency by means of which the dead can speak to the living" (p. 8). The protection and rehabilitation of diverse natural ecosystems can further bolster efforts to preserve and revitalize cultural diversity and, reciprocally, strategies that foster cultural diversity can encourage and stimulate ecodiversity. If the diminishment of one kind of diversity can adversely affect the other, then this threat represents a powerful advocacy argument for the need to promote each, and both (Grant 2012).

\section{Conclusion}

Indigenous knowledge, in combination with new materialism and political ecology discourses, can help us come back down to earth in ways of being and becoming that are ecologically sustainable, preserving the ecodiversity that exists and grows in place, forging egalitarian relationships and a sense of communal responsibility, fostering reverence for ancestors along with nonhuman lives and topographies, and cultivating musical practices that are one with our respective ecosystems. Music educators, who recognize that such actions bring to light and push back against unquestioned hierarchies and social bias, discover that contributing to diversity in music education is inherently political. In foregrounding their students' musical traditions and emphasizing musicking within local contexts of community, 
family, and soundscape, with the guidance of local music makers, these music educators actively support ecodiversity in music education. Indigenous traditions and actions are proving especially vital in this work because they-along with other ecomusicological experiences and forms of local musicking-can facilitate our return to ecodiversity and sustainability, not in the sense of further appropriating or enclosing cultural traditions but in concert with communities as they nurture their musical roots, attuned to their respective geographical locations.

\section{References}

Allen, A. S., \& Dawe, K. (Eds.). (2016). Current directions in ecomusicology: Music, culture, nature. New York: Routledge. Kindle edition.

Atleo, E. R. (Umeek). (2004). Tsawalk: A Nuu-chah-nulth worldview. Vancouver: UBC Press.

Atleo, E. R. (Umeek). (2011). Principles of tsawalk: An Indigenous approach to global crisis. Vancouver: UBC Press.

Basso, K. (1996). Wisdom sits in places: Landscape and language among the Western Apache. Albuquerque: University of New Mexico Press.

Bates, V. C. (2013). Music education unplugged. Action, Criticism, and Theory for Music Education, 12(2), 75-90.

Blanc, N., \& Soini, K. (2015). Cultural and biological diversity: Interconnections in ordinary places. In C. De Beukelaer, M. Pyykkönen, \& J. P. Singh (Eds.), Globalization, culture, and development: The UNESCO convention on cultural diversity (pp. 75-90). New York: Palgrave Macmillan.

Bridge, G., McCarthy, J., \& Perreault, T. (2015). Editors' introduction. In T. Perreault, G. Bridge, \& J. McCarthy (Eds.), The Routledge handbook of political ecology (pp. 3-18). New York: Routledge. Kindle edition.

Carson, R. (2002). Silent spring: The classic that launched the environmental movement. New York: Mariner Books. (Original work published 1962).

Clarke, E., DeNora, T., \& Vuoskoski, A. (2015). Music, empathy and cultural understanding. Physics of Life Reviews, 15(December), 61-88. https://doi.org/10.1016/j.plrev.2015.09.001.

Ehrlich, P. R., \& Wilson, E. O. (1991). Biodiversity studies: Science and policy. Science, 253(5021), 758-762.

Elsey, C. (2013). The poetics of land and identity among British Columbia Indigenous peoples. Halifax: Fernwood Publishing.

Esteva, G., \& Prakash, M. S. (2014). Grassroots postmodernism: Remaking the soil of cultures (2nd ed.). London: Zed Books Ltd.

Fletcher, R. (2017). Connection with nature is an oxymoron: A political ecology of "nature-deficit disorder". The Journal of Environmental Education, 48(4), 226-233. https://doi.org/10.1080/ 00958964.2016.1139534.

Fox, N. J., \& Alldred, P. (2017). Sociology and the new materialism: Theory, research, action. Thousand Oaks: Sage Publications. Kindle edition.

Grant, C. F. (2012). Analogies and links between cultural and biological diversity. Journal of Cultural Heritage Management and Sustainable Development, 2(2), 153-163. https://doi.org/ 10.1080/08145857.2011.576648.

Henderson, J. A., \& Zarger, R. K. (2017). Toward political ecologies of environmental education. The Journal of Environmental Education, 48(4), 285-289. https://doi.org/10.1080/00958964. 2017.1336978.

Ignace, M., \& Ignace, R. (2018). Secwépemc people, land, and laws. Montréal: McGill-Queen's University Press. 
Intergovernmental Panel on Climate Change. (2018). Global warming of $1.5^{\circ} \mathrm{C}$. https://www.ipcc. ch/sr15/. Accessed 12 June 2020.

Jordan, S. M. R., Barraclough, T. G., \& Rosindell, J. (2016). Quantifying the effects of the break up of Pangea on global terrestrial diversification with neutral theory. Philosophical Transactions of the Royal Society of London. Series B, Biological Sciences, 371(1691). https://doi.org/10.1098/ rstb.2015.0221.

Kymlicka, W., \& Walker, K. (2012). Rooted cosmopolitanism: Canada and the world. Vancouver/ Toronto: UBC Press.

Lewis, S. L., \& Maslin, M. A. (2018). The human planet: How we created the Anthropocene. New Haven: Yale University Press.

MacLure, M. (2016). The 'new materialisms': A thorn in the flesh of critical qualitative inquiry? In G. Cannella, M. S. Perez, \& P. Pasque (Eds.), Critical qualitative inquiry: Foundations and futures (pp. 92-111). New York: Routledge. Kindle edition.

Prakash, M. S., \& Esteva, G. (2008). Escaping education: Living as learning within grassroots cultures (2nd ed.). New York: Peter Lang.

Prest, A. (2013). The importance of context, reflection, interaction, and consequence in rural music education practice. Journal of Research in Rural Education, 28(14), 1-13. http://sites.psu.edu/ jrre/wp-content/uploads/sites/6347/2014/02/28-14.pdf.

Ridington, R., \& Ridington, J. (2006). When you sing it now, just like new: First Nations poetics, voices, and representations. Lincoln: University of Nebraska Press.

Schippers, H. (2016). Sound futures: Exploring the ecology of music sustainability. In H. Schippers \& C. Grant (Eds.), Sustainable futures for music cultures: An ecological perspective (pp. 1-18). New York: Oxford University Press. Kindle edition.

Sercombe, L. (2009). The story of dirty face: Power and song in Western Washington Coast Salish myth narratives. In T. Browner (Ed.), Music of the first nations: Tradition \& innovation in Native North America (pp. 34-53). Chicago: University of Illinois Press.

Shevock, D. J. (2017). Eco-literate music pedagogy. New York: Routledge.

Simonett, H. (2016). Of human and non-human birds: Indigenous music making and sentient ecology in Northwestern Mexico. In A. S. Allen \& K. Dawe (Eds.), Current directions in ecomusicology: Music, culture, nature (pp. 99-108). New York: Routledge.

Snyder, R., Williams, D., \& Peterson, G. (2003). Culture loss and sense of place in resource valuation: Economics, anthropology and Indigenous cultures. U.S. Forest Service. https://www. fs.fed.us/rm/value/docs/culture_sense_place_resource_valuation.pdf. Accessed 12 June 2020.

Titon, J. T. (2016). Why Thoreau? In A. S. Allen \& K. Dawe (Eds.), Current directions in ecomusicology: Music, culture, nature (pp. 69-80). New York: Routledge. Kindle edition.

Weil, S. (2002). The need for roots. New York: Routledge. (Original work published 1949).

Werito, V. (2014). Understanding Hózhó to achieve critical consciousness: A contemporary Diné interpretation of the philosophical principles of Hózhó. In L. L. Lee (Ed.), Diné perspectives: Revitalizing and reclaiming Navajo thought (pp. 25-38). Tucson: The University of Arizona Press.

Yeh, E. T., \& Bryan, J. (2015). Indigeneity. In T. Perreault, G. Bridge, \& J. McCarthy (Eds.), The Routledge handbook of political ecology (pp. 531-544). New York: Routledge. Kindle edition.

Vincent C. Bates is an Associate Professor of Teacher Education at Weber State University in Ogden, Utah, where he teaches arts integration and educational foundations. Vincent's research interests include intersections between music education, place, and social class. Prior to WSU, he was a member of the music faculty at Northwest Missouri State University for 6 years and taught K-12 music and art in Eureka, Utah for 12 years.

Daniel J. Shevock is a music education philosopher and author of the monograph, Eco-Literate Music Pedagogy, published by Routledge, and a blog at eco-literate.com. He teaches at Penn State Altoona and plays jazz vibraphone. Dan's scholarship blends creativity, ecology, and critique. 
Anita Prest is Assistant Professor of Music Education in the Department of Curriculum and Instruction at the University of Victoria (British Columbia, Canada). Her current research, funded by the Social Sciences and Humanities Council of Canada (SSHRC), examines the ways in which public school music educators in rural British Columbia, together with First Nations community members, facilitate the appropriate embedding of local Indigenous knowledge, pedagogy, and cultural practices in music classes. Prior to her appointment, Anita taught K-12 music for 20 years in rural and metropolitan settings.

Open Access This chapter is licensed under the terms of the Creative Commons Attribution 4.0 International License (http://creativecommons.org/licenses/by/4.0/), which permits use, sharing, adaptation, distribution and reproduction in any medium or format, as long as you give appropriate credit to the original author(s) and the source, provide a link to the Creative Commons license and indicate if changes were made.

The images or other third party material in this chapter are included in the chapter's Creative Commons license, unless indicated otherwise in a credit line to the material. If material is not included in the chapter's Creative Commons license and your intended use is not permitted by statutory regulation or exceeds the permitted use, you will need to obtain permission directly from the copyright holder. 